Original Research Article

\title{
Study of Broiling effect on Nutritional Quality and Phytochemical Content in Sweet Corn
}

\author{
Verma, Divya and Pareek, Navita \\ Department of Foods \& Nutrition, Faculty of Home Science, Banasthali Vidyapith, Rajasthan, India. \\ Corresponding Author: vermadei865@gmail.com
}

\begin{abstract}
A R T I C L E I N F O
Received: 07 February 2018 | Accepted: 22 April 2018 | Published Online: 15 August 2018

DOI: $10.31786 / 09756272.18 .9 .1 .123$

EOI: 10.11208 /essence.18.9.1.123

Article is an Open Access Publication.

This work is licensed under Attribution-Non Commercial 4.0 International

(https://creativecommons.org/licenses/by/4.0/)

CThe Authors (2018). Publishing Rights @ MANU_ICMANU \& ESSENCE_-IJERC.
\end{abstract}

\section{A B S T R A C T}

Sweet corn is one of the staple foods in many nations across the world. It has high quality phytonutrition profile comprising of dietary fiber, vitamins and antioxidants in addition to minerals in moderate proportions. The aim of this study is to investigate the effect of broiling on the proximate composition, antioxidants activity and phytochemicals content in sweet corn. Broiling and drying was done for the preparation of dry powder and aqueous extract of sweet corn. Proximate composition, phytochemical content and antioxidant activity of the sample were determined through standard procedures. The results indicated that moisture, protein, carbohydrate, fat, iron, calcium and vitamin $\mathrm{C}$ content decreases and fiber and ash content increases after broiling of sweet corn. There was no qualitative changes has been seen in phytochemicals and antioxidants content (Tannin, Phytic acid, Flavonoids and Phenols) after broiling of sweet corn.

\section{K E Y W O R D S}

Sweet Corn | Broiling | Proximate composition | Antioxidants | Phyto-chemicals

\section{I T A T I O N}

Divya verma and Dr. Navita Pareek : Study of Broiling effect on Nutritional Quality and Phytochemical Content in Sweet Corn. ESSENCE Int. J. Env. Rehab. Conserv. IX (1): 185-188. 


\section{Introduction}

Sweet corn is one of the staple foods in many nations across the world. There are many varieties of corn which are used for human's food and are processed to make food ingredients, like corn syrup, corn starch etc (Temple, 2000). Sweet corn is a gluten free cereal and may be used safely in celiac disease. It contains healthy amounts of some important minerals like zinc, magnesium, copper, iron and manganese (Bernhardt, 2006). Cooking methods affect both physical and chemical changes resulting in an increase or decrease in proximate composition, phytochemical contents, particularly antioxidants present in sweet corn. Fresh sweet corn has been consumed broadly by broiling since past times (Rhoads et al., 2008). Cereals when subjected to heat result in many changes there is some destruction of protein, lipid and vitamin which is detrimental to the nutritional value of cereals. Many studies have shown that diet rich in cereals are protective against diseases and populations that consume such diets have the higher plasma antioxidant status and exhibit a lower risk of cancer and cardiovascular diseases. Grilling brings about many changes in sweet corn (Sood et al., 2002).Therefore the main objective of the present study was to determine the effects of broiling on the proximate composition, phytochemical content and antioxidant activity of sweet corn, with the hope that the findings would guide future practice of suitable cooking methods in order to minimise the degradation of nutrients in sweet corns.

\section{Materials and Methods}

Collection and preparation of Sample: Sweet corn was collected from the Department of Agriculture in Banasthali Vidyapith (Rajasthan). It was broiled at $64^{\circ} \mathrm{C}$ and then powdered it after sun drying. Aqueous extract was also prepared for phytochemical testing.

Proximate and mineral composition of raw and broiled sweet corn: Raw and broiled sweet corn powder were subjected to the determination of the moisture, ash, crude fiber, protein, $\mathrm{CHO}$, fat, and minerals like calcium and iron through standard technique.

Moisture content in the sweet corn samples were estimated according to the method described in AOAC (2000). Drying, cooling and weighing were done until the weight of the sample become constant. Mineral ash content was estimated according to the method described in NIN (2003) and it was basically done for the estimation of minerals like calcium and iron. Crude fiber content in the sweet corn samples were estimated by the method described in the AOAC (2000). Hydrogen chloride and sodium hydroxide were used as a reagent for the estimation of crude fiber. Fat content was estimated in a dry sample following the removal of moisture and petroleum ether was use as a reagent for its estimation. It is estimated by the method given in the Sharma (2007). Protein content of the sweet corn samples was estimated by Kjeldhal method given in AOAC (2000) and in this method digestion, distillation and titration were done on the sample for the protein estimation. Carbohydrate content is calculated by the sum of moisture, protein, ash, fat and crude fiber were subtracted from 100 to get the carbohydrate content of sample. The calcium content in sweet corn was determined using titrimetric method given in NIN (2003). The iron content was estimated following the Wong's method described in NIN (2003).

\section{Estimation of antioxidants and phytochemical}

content: Ascorbic acid content in sweet corn was estimated by the method given in AOAC (2000). For the estimation of Vitamin ' $\mathrm{C}$ ' the sample was titrated against, 6 dichlorophenol indophenols solution. Phytochemical content in raw and broiled sweet corn was determined by the qualitative method. Total flavonoids were estimated by the method of Luximon-Ramma et al., (2002). The total polyphenol contents were determined according to the method of Folin and Denis (1915). Method of Schanderl (1970) was employed for determination of tannins in the sample of sweet corn. And phytic acid content was estimated by the method of Wheeler and Ferrel (1971).

\section{Statistical Analysis}

Descriptive statistics was used to analyze the data. The Student's $t$-test was applied to evaluate the effect of cooking treatments (broiling) on the studied parameters of Sweet Corn. The values of the cooked samples were compared with the fresh sweet corn sample. 


\section{Observation and Discussion}

Proximate nutrients in raw and broiled sweet corn have been shown in Table 1. It indicates the percentage loss and percentage gain in proximate composition in the sample during Broiling.

\section{Proximate and mineral Composition}

Proximate composition of raw and broiled sweet corn are presented in Table 1. Ash and crude fiber content were increases whereas moisture, crude fat, protein and calcium were decrease after broiling. There was no significant $(\mathrm{P}>0.05)$ difference in crude fiber and protein contents of raw and broiled sweet corn. The same value of crude fiber and protein were reported in the other studies (Norwood et al., 2001 and Abdul Rahman et al, 2001). Broiling significantly $(\mathrm{P}<0.05)$ decreases the moisture, fat and carbohydrate contents. The same value was found in the other studies (Walker et al, 2013, Norwood et al., 2001 and Abdul Rahman et al., 2001). Ash content was significantly $(\mathrm{P}<0.05)$ increased by broiling and the same value was found in the other study (Walker et al., 2013). There was no significantly $(\mathrm{P}<0.05)$ reduction in the iron and calcium content of sweet corn after broiling. And the same value for iron and calcium were found in the other study (Rahman et al., 2001).

\begin{tabular}{|c|c|c|}
\hline Constituents & $\begin{array}{c}\text { Raw } \\
\text { Sweet } \\
\text { Corn }\end{array}$ & $\begin{array}{c}\text { Broiled } \\
\text { Sweet Corn }\end{array}$ \\
\hline Moisture $(\mathrm{g} / 100 \mathrm{~g})$ & $75.1 \pm 0.17$ & $62.1 \pm 0.34 *$ \\
\hline $\operatorname{Ash}(g / 100 g)$ & $8.96 \pm 0.5$ & $10.16 \pm 0.11 *$ \\
\hline Crude fat $(\mathrm{g} / 100 \mathrm{~g})$ & $10.3 \pm 0.17$ & $9.9 \pm 0.17 *$ \\
\hline Crude fiber(g/100g) & $1.43 \pm 0.23$ & $1.96 \pm 0.11^{\mathrm{NS}}$ \\
\hline $\operatorname{Protein}(\mathrm{g} / 100 \mathrm{~g})$ & $\begin{array}{c}0.13 \pm 0.02 \\
0\end{array}$ & $\begin{array}{c}0.07 \pm 0.005 \\
\text { NS }\end{array}$ \\
\hline $\begin{array}{c}\text { Carbohydrate } \\
(\mathrm{g} / 100 \mathrm{~g})\end{array}$ & $\begin{array}{c}12.99 \pm 0.1 \\
5 \\
\end{array}$ & $12.03 \pm 0.15^{*}$ \\
\hline $\operatorname{Iron}(\mathrm{mg} / 100 \mathrm{~g})$ & $3.80 \pm 0.01$ & $3.72 \pm 0.03^{\mathrm{NS}}$ \\
\hline Calcium(mg/100g) & $\begin{array}{c}10.01 \pm 0.0 \\
1\end{array}$ & $9.01 \pm 0.01 \mathrm{NS}$ \\
\hline
\end{tabular}

Table 1: Proximate analysis of Raw \& Broiled Sweet Corn on dry weight basis

Values are mean of three replicates \pm SD and expressed on $\mathrm{g} / \mathrm{100g}$ sample

* Indicates significant difference at $\mathrm{P}>0.05$ levels, NS - Indicates non-significant Antioxidants and Phytochemicals

Vitamin ' $C$ ' content in the sweet corn was nonsignificantly $(\mathrm{P}<0.05)$ reduced after the broiling of sweet corn and it is presented in the Table 1. Similar result was found in the other study (Sood et al., 2002). Antioxidant and phytochemical content in raw and broiled sweet corn have been shown in Table 2 and they were assessed by the qualitative method. Results indicate that the antioxidants (Polyphenols and Flavonoids) were present in both raw and broiled sweet corn and phytochemicals (Tannins and Phytic acid) were also present in both raw and broiled sweet corn.

\begin{tabular}{|c|c|c|}
\hline $\begin{array}{c}\text { Antioxidants/ } \\
\text { Phytochemi- } \\
\text { cals }\end{array}$ & $\begin{array}{c}\text { Raw } \\
\text { Sweet Corn }\end{array}$ & $\begin{array}{c}\text { Broiled } \\
\text { Sweet } \\
\text { Corn }\end{array}$ \\
\hline $\begin{array}{c}\text { Vitamin C } \\
\text { (mg/100g) }\end{array}$ & $5.67 \pm 0.06$ & $4.26 \pm 0.05^{\mathrm{NS}}$ \\
\hline $\begin{array}{c}\text { Polyphenols (mg } \\
\text { GAE/100g) }\end{array}$ & Positive & Positive \\
\hline $\begin{array}{c}\text { Flavonoids(mg } \\
\text { QU/100g) }\end{array}$ & Positive & Positive \\
\hline $\begin{array}{c}\text { Tannins } \\
\text { (mg/100g) }\end{array}$ & Positive & Positive \\
\hline $\begin{array}{c}\text { Phytic Acid } \\
\text { (mg/100g) }\end{array}$ & Positive & Positive \\
\hline
\end{tabular}

Table 2: Qualitative assessment of Antioxidants and Phytochemical Constituents in Sweet Corn

\section{Conclusions}

Being healthy requires physical and mental fitness and therefore to be healthy one needs to be optimally nourished, but as the population increases day by day their nutritional requirements are not met with the recommended allowances due to excess or imbalance of nutrients.. Moisture, fat, carbohydrate were significantly and protein, iron, calcium, vitamin $\mathrm{C}$ content were nonsignificantly decreased after the broiling of sweet corn. Ash content was significantly and crude fiber content was non-significantly increased after the broiling of sweet corn. Among phytochemical content phytic acid, tannins and in Antioxidant factors phenols and flavonoids were present qualitative in raw as well as broiled sweet corn. Thus it is important to choose the right method of cooking for maintaining a good health status and also using it in a right manner.

\section{Acknowledgement}

No words are befitting enough to express my humble and sincere feeling of gratitude my supervisor Dr. Navita Pareek, Associate professor, De 
partment of Food Science and Nutrition, Faculty of Home Science, Banasthali Vidyapith for all the active support to a meaningful conclusion. I wish to express my profound gratitude to Prof. Aditya Shastri, director, Banasthali Vidyapith for his kind permission to undertake the study in this university. I would also like to thank Dr. Sheel Sharma (Head of Department), Department of Food Science and Nutrition, Banasthali University for his valued inspiration, generous and parental affection.

\section{References}

AOAC. Official method of analysis ( $17^{\text {th }}$ Edition); (Association of official and Analytical Chemistry) (by Dr. William Horwitz). Gaithersburg, MD, USA 2000.

Bernhardt, S. and Schlich, E. (2006): "Impact of different cooking methods on food quality: Retention of lipophilic vitamins in cereals". Journal of Food Engineering, 77: 327-333.

Folin O. and Denis W.; (1915): "A colorimetric estimation of phenol and derivatives in urine". J. Biol. Chem., 22; 305-308.

Luximon-Ramma A.; Bahorum T.; Soobratee M. A. and Aruoma O. I.; (2002): "Antioxidant activities of flavonoid compounds in extract of Cassia Fistula". Journal of Agriculture and food chemistry, 50: 5042-5047.

Norwood, C. A. (2001): "Planting date, hybrid maturity andplant density effect on soil water depletion and yield of dry land corn”. Agron J. 93: 1034-1042.

Raghuramulu, N.; Madhavan. K., and Kalyanasundaram. S.; (2003): "A Manual of Laboratory Techniques". Hyderabad, India: Indian Council Med Res. P.175-195.

Rehman, A.; Ihsan, H.; I. H. Khalil, H, and M. Iqbal. (2001): "Genotypic Variability for morphological traits among exotic maize hybrids". Sarhad J. Agric., 21(4): 599 602.

Rhoads, F. M.; (2008): "Sweet corn research in north Florida”. Fla. Agri. Expt. Sta. Research Report, Quincy. Vegetable Field Day.

Schanderl, S. H.; (1970): "Methods in Food Analysis". Academic Press, New York,
London Pp709.

Sharma, S. (2007): "Estimation of proximate chemicals composition, Experiments and techniques in biochemistry". Galgotia Publication Pvt Ltd New Delhi, 55-60.

Sood, J.; Gadag, R. N.; Jha G. K. (2002). "Genetic analysis and correlation in sweet corn (Zeamays) for quality traits, field emergence and grain yield". Indian J.Agric. Sci., Vol. 77(9), 613-615.

Temple, N. J. (2000) "Antioxidants and disease: more questions than answer". Nutr. Res., 20 (3), 449-459.

Walker, L.; Tibäck, E.; Svelander, C.; Smout, C.; Ahrné, L.; Langton, M.; Alminger, M.; Loey, A. V. and Hendrickx, M. (2013): "Thermal pretreatments of sweet corn using different heating techniques: Effect on quality related aspects". Innovative Food Science and Emerging Technologies, 10(4): 522-529.

Wheeler, E. L. and Ferrel, R. E. (1970): “A method of phytic acid determination in wheat and wheat fractions". Cereal Chemistry. 48. 312-316. 